\title{
K psychologii láskyplného vztahu: pedagogické inspirace se zaměřením na předškolní výchovu
}

\author{
Zdeněk Helus \\ Univerzita Karlova v Praze, Pedagogická fakulta \\ Redakci zasláno 29. 4. 2014 / upravená verze obdržena 13. 7. 2014 / \\ k uveřejnění přijato 6. 8. 2014
}

\begin{abstract}
Abstrakt: Studie klade důraz na osobnostní přístup k vývoji dítěte v doškolní fázi jeho života, tvořící celek vývojových souvislostí, vrcholících vstupem dítěte do mateřské školy. Osobnostní přístup zahrnuje za prvé zřetel k podstatným znakům doškolního dítěte (k jeho odkázanosti, otevřenému prožívání, potencialitám a vývojovému směřování) a za druhé zřetel k zlomovým událostem $\mathrm{v}$ jeho dosavadním vývoji (primárnímu vztahu a připoutání, separačně individualizační tendenci, nástupu asertivního já, včlenění do mateřské školy). Láskyplný vztah je podmínkou, aby vývoj probíhal plnohodnotně, tedy nebyl brzděn, deformován apod. Láskyplný vztah učitelky mateřské školy má specifické znaky a uplatňuje se v její vcítivě tvořivé reflexi nad dítětem jakožto utvářející se osobností.
\end{abstract}

Klíčová slova: osobnostní vývoj, podstatné znaky dětství, láskyplný vztah, situovanost lásky, zlomové vývojové události, předškolní edukace, vcítivě tvořivá reflexe

Tato studie je inspirována osobností a dílem doc. PhDr. Evy Opravilové, CSc. V rozhovoru pro Učitelské noviny (2012, č. 5), kde byla po právu označena jako guru české předškolní pedagogiky, byly připomenuty dvě dominanty jejího celoživotního snažení. Prvou je edukační starost o předškolní dítě. Druhou pak je učitelka mateřské školy, její příprava, kvalifikovanost. Obě dominanty se propojují, poněvadž př́íprava a kompetentnost učitelky mají vyústit především v její způsobilost rozumět dítěti: jeho potřebám, vývojovým možnostem, osobnosti. A na tomto základě být mu výchovným a vzdělávacím dobrodiním. Tímto směrem zde obracím pozornost, s uplatněním psychologického hlediska, které k pedagogickému pohledu doc. Opravilové neodlučně patř́í.

Cílem studie je projasnit chápání určujících souvislostí vývoje dítěte v prvých šesti letech života (tedy v celé doškolní životní fázi), s důrazem na jejich aktualizaci $\mathrm{v}$ podmínkách jeho předškolního začlenění do mateřské školy. 
Obzvláštní význam je zde připisován tzv. láskyplnému vztahu. Ten figuruje $\mathrm{v}$ psychologické literatuře pod různými termíny, s různými významovými posuny. Tato studie je pokusem o jeho reflektující uchopení, inspirované dosavadními výzkumy a odpovídající jeho významu.

\section{Expozice tématu ve čtyřech tézích a následných otázkách}

Teze první. $\mathrm{V}$ této stati jde o dítě $\mathrm{v}$ doškolní fázi ${ }^{1}$ jeho života, se zvláštním důrazem na dítě předškolního věku, začleněné do mateřské školy. Jde nám o ně se zřetelem k edukačnímu úkolu napomoci mu k plnohodnotnému osobnostnímu rozvoji. Klíčovou otázkou pak je: jak tento plnohodnotný osobnostní rozvoj dítěte chápat a v čem vidět ono edukačně účinné napomáhání mu?

Teze druhá. V názvu je použit obrat láskyplný vztah. Tímto termínem odkazujeme na skutečnost značného dosahu: A sice, že láskyplný vztah je nezbytným předpokladem plnohodnotného osobnostního rozvoje dítěte $\mathrm{v}$ jeho doškolním věku. Bereme ovšem v patrnost, že láska - láskyplný vztah je v odborné literatuře traktován pod různými pojmy, poukazujícími na jeho různé, $\mathrm{v}$ mnohém odlišné podoby či projevy, které ovšem mají jednoho společného jmenovatele. Viz např. termíny jako vazba, připoutání, symbiotický vztah, vztah nepodmíněné akceptace apod. Obecně ale platí, že hovoříme-li o láskyplném vztahu, máme na mysli lásku $\mathrm{k}$ dítěti vyjádřenou ve specifické komunikaci, ústící ve vzájemné souznějící naladění, podtržené výraznou emocionalitou. Takováto charakteristika láskyplného vztahu byla ovšem formulována především $\mathrm{v}$ souvislosti s láskou mateřskou, $\mathrm{v}$ prvých obdobích života dítěte. Klade se tedy otázka: A jak je tomu s láskyplným vztahem v edukačním kontextu mateřské školy?

Teze třetí. Akcentujeme-li význam láskyplného vztahu pro dítě v doškolní životní fázi, pak si uvědomujeme, že dítěti nepřináší jenom momentální blaho, ale že jeho účinky mají preformativní důsledky; jinými slovy, významně ovlivňují další běh života a podobu osobnosti. V případě narušení, či dokonce absence láskyplného vztahu hrozí, že nedojde k probuzení empatie, že celá řada osobnostních kvalit jedince se neaktualizuje, že žádoucí, výchozí pozitivní ladění dítěte vůči životu, lidem kolem něho a vlastnímu vývoji bude narušeno. Klade se otázka: Má ale také smyl hovořit o preformativních důsledcích života dítěte $v$ mateřské škole?

1 Rozlišuji zde doškolní vývojovou fázi života - tzn. fázi od narození do nástupu školní docházky a předškolní období, tradičně chápané v rozmezí 3-6 let věku. Doškolní vývojová fáze tedy zahrnuje celý šestiletý životní cyklus v jeho uceleném pojetí, které by vychovatel / učitelka mateřské školy neměla ztrácet ze zřetele. 
Teze čtvrtá. Jak už bylo řečeno, téma pojednáváme se zvláštním důrazem na dítě předškolního věku, začleněné do mateřské školy. Zde se láskyplný vztah artikuluje v edukačním kontextu, kdy vůdčí roli samozřejmě sehrává učitelka. Výsledným cílem stati je, inspirovat ji k překonávání pouhé intuitivní, respektive rutinní práce s dětmi a posílit její vcítivě tvořivou reflexi nad možnostmi realizace jejich plnohodnotného osobnostního rozvoje. S tím se ovšem pojí otázka: Jak chápat tuto vcítivě tvořivou reflexi?

V duchu těchto výchozích, expozičních tézí a navazujících otázek, v souladu s cílem formulovaným ve druhém odstavci úvodu, je studie rozdělena do následujících, navzájem propojených tematických oblastí, respektive kapitol:

(1) Podstatná charakteristika doškolního dítěte jako východisko edukační péče o jeho plnohodnotný osobnostní rozvoj.

(2) K odkázanosti dítěte na láskyplný vztah - reflexe nad pojmem láska.

(3) Láskyplný vztah a zlomové události ve vývoji doškolního dítěte.

(4) Inspirace pro předškolní edukaci - apel na tvořivou reflexi učitelky nad dítětem a jeho edukací.

\section{Podstatná charakteristika doškolního dítěte jako východisko edukační péče o jeho plnohodnotný osobnostní rozvoj}

Doškolní dětství, zahrnující čtyři věková období (novorozenecké, kojenecké, batolecí a předškolní), ${ }^{2}$ tvoří pod určitým úhlem pohledu dobře vyčlenitelný celek navzájem propojených vývojových souvislostí. Dbát tohoto celku je pro porozumění dítěti $\mathrm{v}$ mateřské škole, jeho osobnostním charakteristikám, chování a prožívání, jakož i problémům, se kterými se potýká, velice důležité. To je důvod, proč jsme se pro toto vyčlenění rozhodli.

Při tom dbáme osobnostního pohledu na dítě. Znamená to, že k němu přistupujeme ${ }^{3}$

Viz např. Vágnerová (2012, s. 65-253); Langmeier \& Krejčířová (2006, s. 29-102).

Zde se jedná o podstatně zestručněný pohled, k jehož rozvedené podobě do tzv. osobnostního desatera viz Helus (2009a, s. 125-192; 2009b, s. 12-53; 2014, s. 24-32). 
- Jako k prožívajícímu a jednajícímu subjektu. Tedy bytosti nejen determinované (činiteli dědičnými, vlivy prostředí apod.), ale také a především jako $\mathrm{k}$ bytosti aktivní, jednající z vlastní inciativy.

- Jako k jedinci, vyjadřujícímu ve svém prožívání a jednání svéráznost, tedy individualitu, jejíhož respektování se dožaduje, přičemž tuto individualitu vytváří strukturovaný celek navzájem souvisejících vlastností.

Pakliže bereme jedince jakožto takto chápanou osobnost v úvahu, můžeme mu lépe porozumět, můžeme lépe předvídat, jak a proč se v té které situaci zachová. A také víme lépe, jak jej respektovat a adresně na něho působit.

Hledět na dítě jako osobnost znamená, zabývat se nejen stávajícími projevy osobnostních kvalit, ale také a zejména tím, jak tyto kvality vznikají, vyvíjí se; co jejich žádoucímu vývoji napomáhá, oproti tomu, co jej brzdí či deformuje. Odpovídá to skutečnosti, že dítě je osobností v dynamice jejího konstituování, vznikání a vývojového směřování.

Nezbytnou podmínkou uplatňování osobnostního pohledu v předškolní edukaci je, že budeme brát důsledně v úvahu čtyři podstatné znaky doškolního dítěte, které tvoří jeho

(1) odkázanost,

(2) otevřené prožívání,

(3) potenciality,

(4) vývojové směřování.

Ad (1): Odkázaností dítěte zde nemyslíme toliko jeho závislost jako předpoklad biologického přežití. Pojmem odkázanost

- zde poukazujeme jednak na způsobilost dítěte oddat se druhému člověku, spolehnout se na něj v plné důvěře, spočinout v jeho láskyplné péči;

- a současně, spolu s tím, poukazujeme na pohotovost tohoto druhého člověka odpovídat dítěti láskyplnou péčí, synchronizovanou s projevy jeho potřeb. A to tak, že toto dítě je ubezpečeno $v$ účinnosti opory, na kterou spoléhá. Odkázanost tedy není chápána jako vydanost na pospas nějakým způsobům edukační nadvlády, ale je především láskyplným vzájemným setkáním. 
Tím je také napovězeno, že musíme rozlišovat jednak odkázanost jako podrobenost dítěte tomu, jak je jeho život organizován pečující osobou. Proti tomu za druhé postulujeme odkázanost subjektovou, kdy dítě vyjadřuje své potřeby a touhy a vychovatel je s vcítivou pozorností, se vší vážností bere v úvahu a synchronizuje s nimi své odpovědi. Dochází tak k jedinečnému prožitku dialogického mezilidského sblížení (JÁ-TY, TY-JÁ), který přetrvává jako pozitivní vklad do dalšího života dítěte.

Ad (2): Termínem otevřené prožívání označujeme takové prožívání dítěte, které se pojí s jeho zájmem o to, co se kolem něho děje, čeho stojí za to si všímat a na co se těšit; otevřeně prožívající dítě je zvídavé, rádo experimentuje, protože „objevy“, které činí, a nové zkušenosti, k nimž dospívá, mu dělají radost, obohacují je. K otevřenému prožívání doškolní dítě inklinuje, ale nemusí $\mathrm{k}$ němu dojít: je potencialitou, která se nemusí aktualizovat. Aktualizuje se tehdy, když může spoléhat na blízkou osobu, protože je mu na dosah, když znejistí, nebude si vědět rady, dostane strach, jak si s tím či oním novým poradí.

V protikladu k otevřenému prožívání je např. tzv. kognitivní sevření, tedy prožitkové rozpoložení, kdy se dítěti nejrůznější události v přespř́lišné míře, v důsledku nedosažitelnosti vcítivé opory, vyjevují jako zneklidňující, nebezpečné, př́liš riskantní. Rozsah zájmů a aktivit se tak zužuje na schémata stereotypního sebeubezpečování, že se mně snad nic zlého nestane. Zvláště povážlivou variantou kognitivního sevření je tzv. tunelové vidění, kdy jedince přemáhá strach, že události, nad kterými ztrácí jakoukoliv vládu, spějí k nějakému, někdy těžko konkretizovatelnému, nicméně emočně dotírajícímu bytostnému ohrožení. ${ }^{4}$

Aktualizace otevřeného prožívání napomáhá dítěti v jeho vývoji kognitivním, postojovém, emocionálním - osobnostním. Posiluje jeho sebejistotu, že si dokáže poradit, že je zdatným „objevitelem“, úspěšným „experimentátorem“. A to se pozitivně promítá do následné školní fáze vývoje dítě, pravděpodobně i do dalších životních fází.

Ad (3): Už v předchozím bodu, připomenutím otevřeného prožívání jako potenciality a její aktualizace, bylo otevřeno téma třetího z podstatných znaků doškolního dětství, kterým jsou právě potenciality $v$ širokém a nanejvýš závažném významu. Dítě je nápadné svou omezeností, tím, co ještě neví

$4 \quad$ Viz např́klad Shneidman (1998). 
a neumí, na co ještě nestačí a v čem na ně nelze spolehnout. Tomu odpovídá charakterizování dětství minus znaky, tedy nedostačivostmi v porovnání $\mathrm{s}$ dospělou osobou. Vnímavému vychovateli to ale nezastře edukačně daleko důležitější pohled na široké spektrum vývojových možností - potencialit. Pojem potencialit se často, zejména pak ve spojitosti s nástupem do školy, zužuje na potenciality výkonové. Obecně však, jmenovitě vzhledem $\mathrm{k}$ doškolní vývojové fázi, musíme klást do popředí takové potenciální kvality osobnosti, jako je způsobilost být št’asten; nepoddávat se pocitům bezmoci, ale procitat $\mathrm{k}$ sebevědomí subjektu; vnímat lásku a sympatii druhých a odpovídat jim vlastními projevy láskyplnosti a sympatie; být ohleduplný a radovat se z toho, že jsem udělal radost druhým; brát na sebe zodpovědnost a dostát jí i v konfrontaci s obtížemi apod.

$\mathrm{V}$ protikladu k těmto potencialitám, které označíme termínem pozitivně růstové, ovšem nesmí uniknout nebezpečí aktualizace potencialit negativních, pro jedince i sociální okolí nebezpečných, jako je např. tendence být agresivní, vynucovat si dotěrností, pláčem, zlobením to, co chci mít apod. Mateřská škola, díky svým programům edukační práce s dětskými skupinami, může sehrát při posilování tendence dětí k potencialitám pozitivně růstovým významnou roli.

Ad (4): Díky respektování výše uvedených podstatných znaků doškolního dítěte reflektujícím vychovatelem, tzn. respektování jeho

- subjektové odkázanosti,

- otevřeného prožívání,

- aktualizace pozitivně růstových potencialit

projevuje toto dítě účinný zájem o své směřování do budoucnosti; je v konstruktivním duchu perspektivně orientováno. A to ve vztahu

- k lidem, kterým důvěřuje;

- k úkolům, které je baví zvládat, poněvadž ví, že ve chvílích bezradnosti nezůstane bez pomoci a že úspěch bude zaznamenán, udělá radost jemu i druhým, na které myslí;

- k sobě samému, poněvadž si je vědomo vlastního významu / vlastní hodnoty, takže chce o sebe dbát, musí mu na sobě samém činorodě záležet, podobně jako na něm záleží blízkým druhým. 


\section{K odkázanosti dítěte na láskyplný vztah, reflexe nad pojmem láska}

S odkazy na význam láskyplného vztahu dětství jsme se v předchozím pojednání setkávali často. Připomínala se nám slova vstupní expozice, že láskyplný vztah je nezbytným předpokladem plnohodnotného osobnostního rozvoje dítěte $\mathrm{v}$ jeho doškolním věku. Sama odkázanost doškolního dítěte (jmenovitě tzv. odkázanost subjektová), jako první a výchozí ze čtyř jeho podstatných znaků, je de facto založena na láskyplném vztahu, od kterého se pak odvíjí další vývojová pozitiva, ústící v utváření raných osobnostních kvalit. Pokusme se však tyto exkurzy nyní doplnit reflexí nad samotným pojmem láska, nad psychologickým úsilím o jeho uchopení.

Východiskem je nám zde tzv. prototypický př́stup k fenoménu lásky, který se snaží o reflektující pohled na významná slova přirozeného jazyka, spojený se snahou vyčlenit jejich významovou skladbu. Ukazuje se, že láska je spolu s radostí nejčastějším výrazem pro pozitivní emoce (viz například Slaměník, 2011, s. 24-37; Shaver et al., 1987). Co do významové skladby slova láska klademe do popředí pětici jejích psychologicky akcentovaných znaků, které pospolu vytváří její jedinečnost. Láska je

- cit, emoce,

- mezilidský vztah,

- potřeba,

- ctnost,

- dobrodiní.

Láska jako cit. Máme na mysli cit hluboký, silný a stálý. Co do jejího vývoje, který bývá charakterizován jako emoční scénář (viz Fehr \& Russell, 1984), rozlišujeme např. fázi láskyplného vzplanutí; následného zklidnění, spojeného s prožitkem setrvalého blaha ze spolehlivé vzájemné blízkosti; překonávání problémů a krizí; probuzení moudrosti lásky apod. Pokud po láskyplném vzplanutí následuje ochabnutí citu a pominutí lásky, můžeme hovořit o lásce nenaplněné, která nedoznala plnosti svého vyznění.

Láska jako mezilidský vztah. Lásku charakterizuje empatická oboustrannost, vzájemná úcta, respekt, pohotovost vyjít si vstříc, být si navzájem oporou. V návaznosti na toto je třeba připomenout slova vstupní expozice, že hovo- 
ř́me-li o láskyplném vztahu, máme na mysli specifickou komunikaci, ústící v mezilidské souznění s výraznou emocionální složkou, která toto souznění podtrhuje. Láskyplná komunikace s dítětem daleko přesahuje verbální rovinu - velkou úlohu hrají láskyplné doteky (mazlení, chování, objímání) apod.

Láska jako potreba. Souvisí s touhou dát životu smysl, povznést jej láskou. Dítě frustrované nedostatkem lásky, př́ípadně její málo přesvědčivou komunikací, si ji chce vyplakat, vyprosit, vyzlobit - zlobením vyvolat pozornost a utvrdit se, že o mne také jde, byt' se to projevovalo trestáním, když už ne laskavostí apod.

Láska jako ctnost. Pojem ctnost vyjadřuje skutečnost, že láska, rozvinutá ve svých dosud uváděných kvalitách, přesahuje do roviny etické; zavazuje ke způsobu života, překračujícího libovůli závazkem, od kterého nelze odstoupit. Obsahuje ubezpečení, že jest spolehnutí - láska mne zavazuje, že kdyby se přihodilo cokoliv, zůstanu při tobě. A to se promítá jak do vypjatých, náročných událostí života, tak do běžné každodennosti.

Láska jako dobrodiní. Láska je dobrodiním především ve smyslu vzájemného obdarování - dáváme si navzájem sami sebe, já se dávám tobě jako ty mně.

Takto vyjádřená významová skladba pojmu láska ovšem přesahuje láskyplný vztah mezi dítětem a pečující osobou. Přesto zde byla ve své obecnosti připomenuta, poněvadž může inspirovat k reflektujícímu domýšlení tohoto vztahu v kontextu časovém, sociálním apod. Je třeba vzít např. na vědomí, že láskyplný vztah k dítěti je situován do klimatu rodiny, které vytváří především vzájemný vztah mezi rodiči. Je-li nebo není-li v něm přítomna láska vyznačující se uvedenými znaky, podstatně ovlivní i scénář láskyplného přístupu k dítěti.

Tím byla nepřímo nastolena závažná tematika situovanosti láskyplného vztahu k dítěti v současné společnosti. Láskyplný vztah, či konkrétně respektování podstatných znaků doškolního dítěte, je dalekosáhle ovlivněno podmíněností vztahů dobovými činiteli. A je velmi těžké, mnohdy nemožné jim čelit, obrací-li se v neprospěch vztahu k dítěti a emoční kvality jeho prostředí. Samozřejmě, na prvém místě rodinného. $\mathrm{Z}$ významných výzkumných poznatků, které toto dokládají, vybírám jako ilustrující příklady následující.

Kovařík a Šmolka (1996) shrnují výsledky výzkumu nadace HOSTIA např. $s$ tím, že za nejdůležitější předpoklady spokojeného rodinného života patří především dobrý zdravotní stav, pak - s velkým odstupem - následu- 
jí vzájemná tolerance partnerů a dobré hmotné podmínky. Rodičovství zůstává v porovnání $\mathrm{s}$ těmito hodnotami v pozadí. Závažné je dále zjištění, že až $3 / 5$ mužů v reprodukčním věku odmítalo obětovat se v zájmu dětí; mezi ženami se $v$ podobném duchu vyjádřila $1 / 2$ dotazovaných. Podobné výsledky uvádí např. i Dollase (2001) a jiní.

V souladu s argumentovaným názorem Becka a Gersheimové (1995), že mít děti je v postmoderní, respektive tzv. rizikové společnosti naší doby stále častěji vnímáno jako znevýhodnění materiální („děti přijdou draho“) a kariérní, jako zbavení možnosti žít si svůj život po svém apod., uvádí Helus (2007, s. 143-145), že významnou roli ve zdrženlivém, či dokonce odmítavém postoji k dětem vyvolává i obava, co z nich jednou vyroste a zdali je vůbec zodpovědné v tak nejisté době děti počínat. Rabušic (2002, s. 24) konstatuje, že tendence, nepříznivé pro rodičovství, navozuje individualistický hedonizmus, jehož vůdčím motivem je užít si života a nedělat si starosti s péčí o někoho druhého. Doslova praví: „Dítě již není osou a cílem partnerského vztahu, jako tomu bylo dř́ve, je pouze jednou z mnoha možností realizace jedince, jednou z variant životního stylu, již nabízí postmoderní společnost..." $\mathrm{V}$ rámci individualistické orientace a jejích důsledků pro vztah k rodičovství a dětem sehrává významnou roli kariérní orientace rodičů. Např. z výzkumu Hamplové a kol. (2003) vyplývá, že zejména ženy s vysokoškolským vzděláním dlouhodobě preferují seberealizaci a kariéru, i když také touží po rodině. Její založení a mateřství však odkládají a vesměs se pak omezují na jedno dítě, pokud vůbec nějaké děti chtějí či mohou ještě po odkladech mít.

V podobných př́kladech by bylo možno pokračovat. Vesměs se týkají zdráhavých, ne-li dokonce odmítavých postojů k potenciálnímu rodičovství. Je ale třeba si uvědomit, že i vůči narozeným dětem tato původní zdráhavost může sehrávat významnou negativní roli. Když se posléze ukazuje, že dítě vskutku „přijde draho“, že kariéra je vskutku zmařena, že omezení předchozí volnosti je vskutku značné, vynořují se podvědomě či zcela vědomě emoce, které mohou dítěti škodit. Nemusí být trvalé, mohou vyvstávat toliko nárazově, přesto však jsou svým negativním vyústěním neblaze účinné. Matějček (2005) toto doložil na přetrvávajících negativních sklonech vůči dětem z nechtěného mateřství. Ač matky byly posléze přesvědčeny, že své původní výhrady překonaly a o to více dnes dítě milují, promítly nevědomě do vztahu $\mathrm{k}$ němu určitou míru přetrvávajících pochybností, což se u dítěte projevilo v náznacích deprivačního syndromu. 
Závěrečné shrnutí můžeme formulovat tak, že $\mathrm{v}$ postmoderní, kariérně a individualisticko-hedonicky orientované společnosti ve zvýšené míře hrozí, že láska, láskyplný vztah $\mathrm{k}$ dítěti nenabudou plnosti oněch znaků, které by byly pro jeho plnohodnotný osobnostní rozvoj potřebné. Častými se stávají výkyvy v lásce, odvádění pozornosti od emočních potřeb dítěte odtažitými starostmi a problémy, negativní postoje vzápětí „napravované“ zátěžovou přemírou pečovatelské pozornosti atd. Korektivní či kompenzační úloha mateřské školy za těchto okolností nabývá na zvýšeném významu.

\section{Láskyplný vztah a zlomové události ve vývoji doškolního dítěte}

Vcítivě reflektující rozvinutí láskyplného vztahu k doškolnímu dítěti se vyznačuje ohledem ke zvýšeně senzitivním, možno říci zlomovým událostem v jeho dosavadním a stávajícím osobnostním vývoji. Jinými slovy, láskyplný vztah, má-li být účinný, tzn. napomáhat plnohodnotnému osobnostnímu rozvoji, není stále jenom tímtéž, stále stejně vyjadřovaným pozitivním citem, ale je proměňujícím se emočním scénářem, který bývá označován termínem moudrost lásky. To znamená scénářem dbalým toho, co dítě $\mathrm{v}$ dané vývojové etapě potřebuje, jak se projevuje a $\mathrm{k}$ čemu směřuje. $V$ tomto smyslu si zde povšimněme čtyř takovýchto zlomových událostí. Označíme je jako

- primární vztah, respektive připoutání dítěte a synchronizovaná láskyplná odpověd' na jeho projevy;

- separačně individualizační vývojová tendence;

- nástup asertivního já - identifikace a sociální zrcadlo;

- včlenění do života mateřské školy.

Primární vztah, respektive připoutání dítěte a synchronizovaná láskyplná odpověd' na jeho projevy. Za epochální lze právem považovat př́nos psychodynamicky orientovaných autorů5, kteří prokázali, že raný vztah matka-dítě, př́ípadně později nastupující vztahy mezi členy rodinného jádra, se promítají do prožitkového světa dítěte (do jeho osobnosti) ${ }^{6}$, jako svého druhu výchozí vnitřní model, díky kterému se toto dítě orientuje ve vztazích dalších, poz-

5 Viz zejména Spitz (1965), Bowlby (2012, 2013), Horneyová (2000) a další. Shrnující pohled na př́nosy těchto autorů najdeme např. v díle Mitchella a Blackové (1999, s. 43 a násl.).

6 Viz tezi o dítěti v rodině - rodině v dítěti (Helus, 2013, s. 65-68). 
dějších. Podle toho, jaký model se mu vtiskl do zkušenosti a byl v ní fixován ve svém východiskovém významu, se rozvíjí následné vztahy zdárně či s obtížemi, zdravě nebo patologicky. Např́iklad Horneyová (2000) v tomto duchu rozlišuje, v odvislosti od vztahu primárního, vztahovou orientaci, odvíjející se od vztahu primárního: (a) vstř́cnou orientaci k lidem, (b) úzkostnou orientaci od lidí nebo (c) nenávistnou orientaci proti lidem. A to vždy s dalekosáhlými důsledky.

Bowlby $(2012,2013)$, jehož vliv v této oblasti je asi nejpatrnější, razí termín attachment, překládaný jako připoutání (eventuálně též jako vazba, přilnutí). ${ }^{7}$ Rozumějme tomu tak, že dítě je vedeno primární potřebou připoutat se, přilnout k matce jako zdroji základní životní jistoty, přemáhající bolest a strach související s traumatem rození, respektive s úzkostným vnímáním událostí kolem něho. $\mathrm{V}$ optimálním případě mu matka odpovídá vcítivě láskyplnou péčí, sladěnou s jeho potřebami a projevy. Vztah mezi připoutáním dítěte k matce a její láskyplně pečující odpovědí označil Spitz (1965) termínem cirkulární interakce (nebo též synchronizace).

Bowlbyho spolupracovnice a následovnice Ainsworthová (viz Ainsworth \& Marvin, 1994) pak výzkumně prokázala, že připoutání může nabývat čtyř různých podob či kvalit. Pro další vývoj dítěte je optimální tak zvané bezpečné připoutání, kdy dítě v situacích nejistoty vnímá matku jako skýtající spolehlivou a dostupnou oporu, která je nenechá na pospas pocitům úzkosti a ohrožení. Takovéto optimální připoutání ale není zdaleka samozřejmostí. Pesimální, opačný pól představuje tzv. dezorganizované připoutání, kdy matka dostupná není; i když je fyzicky přítomná, dítě v ní nenachází oporu. A nadto svou náladovou rozkolísaností, atakami hněvu či nenávisti, propadáním odtažitým starostem či zájmům, dítě bytostně znejist’uje, navozuje v něm pocity bazální úzkosti narušující pozitivní vztah k životu, lidem, dění kolem něho.

To potvrzují četné longitudinální studie. Tak například výzkum Lyonsové-Ruthové a kol. (1993) prokázal, že děti s dezorganizovaným připoutáním $\mathrm{v}$ útlém věku se častěji $\mathrm{v}$ předškolním a raně školním období chovaly $\mathrm{k}$ ostatním dětem hostilně, až agresivně, měly závažné potíže s navazování přátelských vztahů se souvěkovci apod. Také častěji než děti, které prožily připoutání bezpečné, hledaly s dotěrnou naléhavostí oporu u učitelů

$7 \quad \mathrm{~V}$ této souvislosti se nám připomíná i termín odkázanost, zmíněný výše, $\mathrm{v}$ souvislosti s tzv. podstatnými znaky doškolního dítěte. 
a vyhlédnutých kamarádů, aniž jim dokázaly plně důvěřovat a získat si je. A naopak, výzkumy Hartupa (1989) či Sroufeho a Fleesona (1986) dokazují, že děti připoutané bezpečně, snáze nachází kamarády, s nimiž dobře, bezkonfliktně vychází, a patří v dětském kolektivu mezi oblíbené.

Obdobně vyzněly kromobyčejně záslužné výzkumy Langmeiera a Matějčka (1974), prokazující že citové strádání v doškolním dětství vede ke vzniku deprivačního syndromu, taktéž přetrvávajícího $\mathrm{v}$ různých podobách až do dospělosti. Nověji tato zjištění potvrdili a novými doklady o sociálních důsledcích deprivace doplnili Koukolík s Drtilovou (1996).

Významným pozitivním důsledkem bezpečného připoutání dítěte $\mathrm{v}$ jeho raném věku pro další osobnostní rozvoj je, že zásadním způsobem napomáhá:

- zdravému vztahu k sobě samému (ve smyslu navození tendence k uvědomování si vlastní hodnoty a následně pak i zodpovědné péče o osobnostní rozvoj);

- pozitivnímu vztahu k druhým lidem (ve smyslu způsobilosti všímat si mezilidské důvěryhodnosti a pohotovosti si pomáhat, být si navzájem oporou);

- konstruktivnímu pohledu na svět jako místu dobrému pro život, v němž se lze nadít spokojenosti, úspěchu, smysluplnosti jednání apod.

Separačně individualizační vývojová tendence. Za druhou zlomově významnou vývojovou událost zde považujeme překonávání oné těsné napojenosti dítěte na pečující osobu, tedy (v Bowlbyho terminologii) překonávání jeho připoutání či vazby. Mahlerová (1975) označuje toto překonávání termínem separačně individualizační tendence. Nejde o nějaký ostrý řez mezi prvým (připoutáním) a druhým (separací-individualizací), ale o řadu přechodů, které ovšem jsou vývojově závažné, prožitkově intenzivní a na reflektující pozornost vychovatele apelující.

Co do svého plného rozvinutí se separačně individualizační tendence rozprostírá do poměrně dlouhého časového úseku - přibližně od 4 měsíců do 4 let věku. Dítě se v něm jako osobnost, individualita hledá a vyžaduje při tom láskyplnou oporu, komunikovanou ovšem nyní podle jiného scénáře, než tomu bylo před tím. Díky této opoře postupně dospívá $k$ významné události svého osobnostního vývoje, ke svému jáskému procitnutí. Tomu odpovídá názor Mahlerové, že se separačně individualizační tendencí a jejím vyústěním souvisí psychologické zrození dítěte. 
Důležité projevy separačně individualizační tendence jdou ruku v ruce s vývojem motoriky dítěte a jeho komunikačních a sociálních zdatností. Např lezení po čtyřech, daleko více pak samostatná chůze a běhání umožňují dítěti důležitý prožitek vzdalování se od pečující osoby a následně pak radost z opětného doteku lásky a blízkosti. Tato cirkulace vzdálení a přiblížení navozuje $\mathrm{v}$ dítěti prožitky sebe sama jako akčního subjektu, který vnáší do mezilidského vztahu dynamiku „dobrodružství" a opětného uvedení situace „na pravou míru“. Oblíbeny jsou např. hry na schovávanou, kdy dítě chce být hledáno a nalezeno, kdy se chce schovat a být objeveno. Stává se dokonce, že dítě v tomto období pečující osobu odstrčí a vysmekne se jí, aby prokázalo sobě i druhým počátek zrodu své svébytnosti; ovšem, je-li vše, jak má být, vzápětí se k této osobě zase přimkne, aby se ujistilo, že je vše stále $\mathrm{v}$ pořádku.

Tato tendence s narůstající rozmanitostí svých projevů je vývojově zcela funkční, ale pro vychovatele ne vždy plně srozumitelná. Může být narušena a dítě je pak ve svých pokusech o prvopočáteční sebevymezování podlomeno. Např́íklad tehdy, když pečovatel/matka je příliš úzkostná a odbíhání dítěte brání, protože by se mu mohlo něco stát. Její úzkost se přenáší následně na dítě a to se začíná svých separačně individualizačních tendencí bát, pojí s nimi pocity viny a potlačuje je. Stává se také, že matka dítě ponechá, „at' si dělá, co chce“; tedy nepřistoupí na hru, v níž dítěti jde o to, aby bylo hledáno a nalezeno, aby se mohlo nechat nalézt a tím hledajícího potěšit. Také v tomto př́padě hrozí, že separačně individualizační tendence se plně nerozvine, že cesta ke vznikající svébytnosti bude v samém zárodku narušena.

Nástup asertivního já - sociální zrcadlo a identifikace. Z logiky věci vyplývá, že separačně individualizační tendence má své přirozené vyvrcholení, když dítě vyjádří sebe sama jako JÁ. Slovo „já“ zaznamená pozorný vychovatel ve výrazivu dítěte zpravidla na samém konci druhého roku jeho života. Jedná se o důležitou událost, poněvadž dítě takto vyjadřuje řádově vyšší stupeň své aspirace být subjektem. To dokládá krátce poté častý obrat „já sám“, potvrzující, že JÁ je asertivní, prosazující se; jedinec jakožto JÁ žádá pro sebe respekt co do uznání svých schopností a práva pokusit se zvládnout bez pomoci apod. Jáská asertivita ovšem může být pro vychovatele obtížná, mnohdy dokonce nepřijatelná. Zejména pojí-li se s ní jeho obava, že šlo-li by to takto dál, mohlo by mu dítě „přerůst přes hlavu“ a že je třeba přistoupit $\mathrm{k}$ jeho rozhodnému ovládnutí. To ovšem s sebou nese nebezpečí, že dítě své 
akčně aspirující já potlačí, nedovolí mu se rozvinout. Zde je jedna z vážných prríčin paralyzování vnitřního zdroje realizace vývojových potencialit (viz výše). Vychovatel má reflektovat skutečnost, že jáská asertivita je tažnou silou intenzity prožívání i jednání.

Procitající JÁ se neoddělitelně pojí s vývojem sebepojetí - tedy pohledu na sebe sama. Dítě své sebepojetí nedokáže verbalizovat (a pokud, pak jen velmi omezeným, případně zavádějícím způsobem), ale intenzivně je prožívá se značnými důsledky pro jednání: sebepojetí má tedy autoregulační dopady. Pro vývoj sebepojetí jsou podstatné dva mechanizmy:

- mechanizmus sociálního zrcadla,

- mechanizmus identifikace.

Sociálním zrcadlem myslíme to, že dítě z reakcí významných osob svého okolí (referenčních osob) vyvozuje, jaké je: chytré, šikovné, statečné, hezké, pořádné; nebo naopak nešikovné, hloupé, zlobivé... Poněvadž ještě nedokáže informace o sobě, plynoucí ze sociálního zrcadla, kriticky zvažovat, porovnávat, korigovat atd., tedy poněvadž je prožívá bez odstupu a nadhledu, je jimi fatálně determinováno. Blízké osoby jeho okolí toto mnohdy nedohlíží a impulzivními, rádoby výchovnými atakami mohou pozitivní jáské sebepojetí dítěte podlomit. Důsledkem jsou pak stavy bezmoci, provinilosti, méněcennosti, podvazující zdravou jáskou asertivitu. Láskyplnost se zde projevuje v tom, že sociální zrcadlo právě naopak tuto zdravou jáskou asertivitu podporuje, ovšem s tím, že dítěti pomáhá dát jí náležitý směr.

Identifikace zde znamená, že se dítě stává samo sebou srze někoho druhého, někoho, koho přijalo (zvnitřnilo, interiorizovalo) jako dominantu svého pohledu na sebe, na své jednání a na důležité obklopující události. Jinak řečeno, interiorizační identifikace znamená, že dítě přijalo pohled druhé osoby za pohled svůj a projevuje snahu ř́́dit se jím v situacích, které jsou pro ně důležité. Předpokladem identifikace je

a) bud' láska k druhé osobě, které se chce dítě plně připodobnit, jejíž požadavky na ně kladené bere plně za své, poněvadž ji za její lásku přece nemůže zklamat, nechce jí za žádnou cenu udělat bolest;

b) anebo strach z trestání, $\mathrm{v}$ krajním a pro dítě obzvláště zraňujícím př́ípadě strach z citového zavržení (",už tě nechci vidět“, ,,jdi pryč, neznám tě“, ,hledej si jinou maminku“ apod.). 
Která z těchto dvou hybných sil iniciování identifikačního procesu převládne, má rozdílné důsledky pro konstituování osobnosti; především pro její mravní cítění. $\mathrm{V}$ prvém př́padě se více prosazuje pozitivní vcítivost a nastupuje morálka ohleduplné lidskosti. $V$ případě druhém převládá spíše úzkostná nutkavost nedostat se do potíží, nebýt vystaven násilí, nebýt izolován apod.

V psychoanalytické tradici je s identifikací spojována problematika vzniku tzv. „nadjá“ (superega), tedy vnitřního kontrolního mechanizmu. Pojem nadjá má však i ve zde rozvíjené koncepci osobnostního vývoje podstatný význam. Poukazuje totiž na skutečnost, že konstituujícímu se já je vlastní tendence tak zvaně přesahová. ${ }^{8}$ To znamená, tendence spojovat své já s něčím více, než je egoistická touha užívat si výhradně po svém. Mé já mne spojuje s druhými a zřetel $\mathrm{k}$ nim je de facto zabudován už v jeho jádru, už v počátečních fázích jeho vývoje. Tak je tomu ovšem za př́znivých mezilidských konstelací, daných láskyplností základních vztahů.

Včlenění dítěte do života mateřské školy. Tři dosud charakterizované zlomové událostiv osobnostním vývoji doškolního dítěte nelze brátodděleně; tak, že by předchozí musela skončit, aby mohla nastoupit ta následující. $Z$ výkladu jasně vyplynulo, že každá z těchto událostí má sice své ústř̌ední téma, řeší právě jí přináležející úkol; nicméně však je zde patrné i překrývání, událost následná už je předjímána v té předchozí. A je důležitým nárokem na vychovatele, aby toto předjímání postřehl a napomáhal zavčas adekvátnímu rozvinutí toho, co se teprve nenápadně ohlašuje. To odpovídá výchozímu konstatování první kapitoly této stati; konstatování, že doškolní dětství se svými čtyřmi věkovými obdobími tvoří celek navzájem propojených vývojových souvislostí a že dbát tohoto celku je pro porozumění osobnosti dítěte $\mathrm{v}$ mateřské škole naprosto nezbytné.

Pro zdárný vstup dítěte do mateřské školy je ovšem zvláště důležité, respektovat jeho jáskou asertivnost, charakterizovanou jako tažná síla intenzity prožívání i jednání (viz výše). V prostředí mateřské školy, se širokou nabídkou rozvojetvorných podnětů a aktivizujících situací, nabývá jáská asertivita podoby tzv. expanzivní iniciativnosti. Znamená to, za prvé, že dítě se chce oddávat nadšení z vlastní pohyblivosti, obratnosti, šikovnosti. Proniká zcela novým způsobem do prostoru kolem sebe a opájí se tím. Je už senzomotoricky natolik rozvinuté, že dokáže „divočit“, „lítat", skákat, prolézat atd. To posiluje jeho separačně individualizační tendence, ale stejně tak i jeho jáskou

8 Viz Bravená (2013, s. 66-70). 
asertivitu. Jiným jejím projevem, za druhé, je expanzivita mentální, duševní. Dochází $\mathrm{k}$ takovému rozmachu představivosti, fantazie, myšlenkových pochodů, že dítě si už vykládá svět kolem sebe, „zabývá“ se jím a řeší jej, byt' to bylo jakkoliv ,jenom na jeho způsob“. Zvláště důležitý je jeho objev možnosti něco dělat a prožívat „jakoby“ (viz níže). A konečně, ruku v ruce s tím, jde - za třetí - i expanzivita sociální. Dítě se stává partnerem rozhovorů a diskusí, poněvadž se rádo ptá, vyjadřuje názor, čímž vyvolává u empatických osob sympatizující odezvy, které zase dále povzbuzují, respektive kultivují jeho sociální expanzivní iniciativnost. Zásadní význam mají samozřejmě snahy včlenit se do kolektivu dětí: navazovat kontakty, hrát si spolu, převádět se před druhými, vyměňovat si s nimi hračky, pomáhat si, činit první zkušenosti s altruizmem.

Bylo již v předchozím odstavci řečeno, že za zvláště důležitý je třeba považovat objev dítěte, že existuje nejen svět reálný, ale i svět fantazijní, svět „jenom jakoby“, ovšem fascinující, prožívaný se značnou intenzitou. Díky své fantazijní představivosti dítě dokáže jaksi vyjít ze sebe sama a stát se někým jiným, někde jinde, někdy jindy. Zejména intenzivně se tak děje v hrách na sociální role, které mají pro osobnostní vývoj dítěte mimořádný význam. Dítě si hraje na různá povolání; na různé fascinující postavy ze svého okolí, z pohádek a př́běhů, které mu byly čteny, vyprávěny, které vidělo v televizi. Během hry na sociální role se dítě dokáže do tohoto svého „jinobytí“ vcítit tak silně, že až zapomíná na své skutečné já. Pomocí her na sociální role se také učí vyhraňovat některé své vlastnosti, připodobňovat se ke vzorům, které touží napodobit. Zkouší si samo sebe v situacích, které v realitě nenastaly (třeba ani nastat nemohou), nicméně ale přitahují, jsou pocitovány jako zajímavé či důležité, mají pro vyhraňování individuality význam.

Hry na sociální role dovolují také nahlédnout na věci a lidi z jiné perspektivy, než je ta moje obvyklá - z pozice někoho, na koho si hraji. Proto také bývají označovány jako hry na přesuny sociálních perspektiv: dítě si hraje na maminku a maminka představuje je samotné. S tím pak souvisí vznik elementárního předstupně způsobilosti zaujmout nadosobní (respektive odosobněné) hledisko; tato způsobilost se ovšem rozvine mnohem později, zde však má svůj významný předstupeň.

Hry na sociální role rovněž umožňují kompenzovat frustrace, kterými dítě trpí. Různá omezení a ponížení, různé obavy a úzkosti. Viz jmenovitě hry na hrdinu, který má sílu a je obratný, který umí, co já bych také rád uměl, 
který se nebojí a dokáže překonat hranice obvyklých možností... Dítě se tak určitým způsobem vymaňuje ze své omezenosti a uniká jejím neúměrně deptajícím účinkům. To vše má pro dítě a jeho vývoj mimořádný význam je vskutku zlomovým objevem! A mateřská škola zde nabízí široký realizační prostor.

Svět prožívaný a realizovaný ,jen jakoby“ má tedy pro vývoj osobnosti předškolního dítěte značný pozitivní význam, nesmí ale odvádět od světa reálného. I ten charakterizuje objev velkého dosahu a mateřská škola v něm sehrává klíčovou roli. Je to objev přináležení do dětského společenství, bohatého na př́ležitosti porovnávat se navzájem, vycházet si vstříc, pomáhat si, objevovat sebe sama jako podobného těm druhým či odlišného od nich, stejně jako objevovat ty druhé jako mně podobné či ode mne odlišné. Při dobrém edukačním působení mají tyto zkušenosti performativní význam pro konstituování lidskosti v prožívání a jednání.

\section{Inspirace pro předškolní edukaci, apel na tvořivou reflexi učitelky nad dítětem a jeho edukací}

$\mathrm{Z}$ předchozích tří kapitol této studie vyplynulo, že má-li být učitelka mateřské školy garantem plnohodnotného osobnostního rozvoje dětí, svěřených do její edukační péče, nemůže být toliko intuitivním, rutinním pedagogem. Požadavek na úplné akademické vzdělání je plně legitimní. Je ale třeba dodat, že toto vzdělání má vést $\mathrm{k}$ tvořivé reflexi nad možnostmi realizace tohoto rozvoje a nad tím, co mu brání.

- Reflexí pak myslíme domýšlení souvislostí, které jsou pro edukační pochopení, rozhodování a jednání podstatné.

- Tvořivou reflexí myslíme hledání východisek z těžkostí a překonávání problémů cestami, které třeba nejsou nasnadě, poněvadž přesahují rámec rutinních zvyklostí; edukace nemá být toliko aplikací poznatků a metodických postupů, ale - s jejich využitím - má být tvorbou ku zdaru edukačního učitelova dobrodiní pro svěřené děti.

- A konečně vcítivě tvořivou reflexí myslíme to, že pedagog nevnímá dítě jako objekt svého působení, ale jako subjekt, s nímž ve svém edukačním úsilí sounáleží; jehož pozici, předpoklady, zájmy apod. nezvažuje toliko ze svého úhlu vidění, ale i z úhlu vidění jeho, které se snaží pochopit a respektovat. 
Vcítivě tvořivá reflexe, v souladu s předchozími kapitolami, je tematicky orientována na podstatné znaky doškolního dítěte, jmenovitě na jeho odkázanost, na jeho otevřené prožívání, na jeho potenciality a na jeho vývojové směřování. Dále, je tematicky orientována na porozumění zlomovým obdobím v dosavadním osobnostním vývoji dítěte a jeho aktuálním důsledkům. Ty je třeba brát v úvahu v trojím významu.

(1) Za prvé, ve významu vývojem dosažených pozitiv, v př́padě, že dítě vyrůstalo v podmínkách jeho vývoji př́iznivých. Tato pozitiva učitelka podtrhuje, posiluje a dále rozvíjí.

(2) Za druhé, ve významu limitů v dosavadním vývoji jde o př́pady, kdy dítě neaktualizovalo své potenciality anebo nedosáhlo vývojové úrovně, kterou máme oprávnění předpokládat, která je obvyklá a žádoucí. Edukačním úkolem pak je vývojové limity překonat, dotvářet to, co bylo během dosavadního vývoj z různých důvodů zanedbáno.

(3) A konečně ve významu narušeného vývoje nepříznivými okolnostmi života dítěte. Edukačním úkolem pak je kompenzace nedostatků, přetváření postojové a motivační struktury osobnosti, korekce traumatických zážitků, eliminace patologických sklonů apod.

Obrátíme-li nyní pozornost k názvu této studie a jejímu výchozímu vymezení, musíme se ptát, platí-li i pro edukační působení učitelky mateřské školy postulát nezbytnosti láskyplného vztahu. Na jedné straně se setkáváme s názorem, že podstatným znakem veškeré edukace je kladení požadavků, úkolování, kontrola plnění a hodnocení dle dosažených výsledků. Láska může razantnost sledování těchto znaků edukace oslabit, možno říci „změkčit", př́ipadně znemožnit. Proti podobným názorům se svého času ostře ohradil Klafki (1977) argumentováním, že pedagogická láska musí být jedním ze znaků pedagogického vztahu, jakožto jednoho z nejdůležitějších vztahů mezi lidmi. V návaznosti pak Helus (2009a) rozvíjí důraz na tzv. pedagogické ctnosti, které spolu s profesionalitou a vědomím poslání tvoří základní sloupy učitelského povolání.

Pedagogická láska, respektive láskyplný vztah v edukačním mezilidském prostoru znamená, že učitel/učitelka mateřské školy poskytuje dítěti přesvědčivý prožitek, že jí na něm záleží. Že ač je jedním mezi ostatními, je přesto vnímáno a respektováno ve své individualitě. Úkoly a požadavky, které jsou na ně kladeny, jsou učitelkou vcítivě a tvořivě reflektovány ve vztahu $\mathrm{k}$ jeho 
předpokladům je zvládnout. A s případnými problémy při tomto zvládání se pojí učitelčino nápomocné jednání, díky kterému si dítě uvědomuje význam lidské opory v situacích nejistoty a zátěže, a to tak, že se s učitelkou v tomto směru identifikuje a cítí potřebu ji napodobovat.

\section{Literatura}

Ainsworth, M. D., \& Marvin, R. S. (1994). On the shaping of attachment theory and research. Monographs of the society for research in child development, 60(2-3), 3-21.

Beck, U., \& Beck-Gernsheim, E. (1995). The normal chaos of love. Cambridge: Polity Press.

Bowlby, J. (2012). Vazba. Praha: Portál.

Bowlby, J. (2013). Odloučení. Praha: Portál.

Bravená, N. (2013). Transcendování a nové podněty pro edukaci obratu. In Z. Helus, N. Bravená, \& M. Franclová (Eds.), Perspektivy učitelství (s. 49-92). Praha: Univerzita Karlova, Pedagogická fakulta.

Dollase, R. (2001). Veränderte Kindheit. In D. H. Rost (Ed.), Handwörterbuch pädagogische Psychologie (s. 741-749). Weinheim: Beltz PVU.

Fehr, B., \& Russell, J. A. (1984). Concept of emotion viewed from a prototype perspective. Journal of Experimental Psychology: General, 113(3), 464-486.

Hamplová, D., Rychtaříková, J., \& Pikálková, S. (2003). České ženy, vzdělání, partnerství, reprodukce a rodina. Praha: Sociologický ústav AV.

Hartup, W. W. (1989). Social relationships and their developmental significance. American Psychologist, 44(2), 120-126.

Helus, Z. (2007). Sociální psychologie pro pedagogy. Praha: Grada.

Helus, Z. (2009a). Dítě v osobnostním pojetí. Praha: Portál.

Helus, Z. (2009b). Osobnost a její vývoj. Praha: Univerzita Karlova, Pedagogická fakulta.

Helus, Z. (2013). Dítě v rodině - rodina v dítěti. In M. Kocurová, J. Klugerová, \& A. Bosáková (Eds.), Rodina v II. Deceniu 21. století (s. 64-73). Praha: Univerzita J. A. Komenského.

Helus, Z. (2014). Edukace jako projev starosti o člověka. In R. Jedlička (Ed.), Teorie výchovy tradice, současnost, perspektivy. Praha: Karolinum.

Horneyová, K. (2000). Neuróza a lidský růst. Praha: Triton

Klafki, W. (1977). Das pädagogische Verhältnis. In W. Klafki (Ed.), Erziehungswissenschaft, Bd. 1 (s. 55-91). Frankfurt am M.: Fischer Verlag.

Koukolík, F., \& Drtilová, J. (2008). Vzpoura deprivantů. Praha: Galen.

Kovařík, J., \& Šmolka, P. (1996). Současná rodina. Praha: Asociace manželských poradců.

Langmeier, J., \& Matějček, Z. (1974). Psychická deprivace v dětství. Praha: Avicenum.

Langmeier, J., \& Krejčířová, D. (2006). Vývojová psychologie. Praha: Grada.

Lyons-Ruth, K., Alpern, L., \& Repacholi, B. (1993). Disorganized infant attachment classification and maternal psychosocial problems as predictors of hostile-aggressive behavior in the preschool classroom. Child Development, 64(2), 572-585.

Mahler, M. S. (1975). The psychological birth of the human infant. New York: Basic Books.

Matějček, Z. (2005). Výbor z díla. Praha: Karolinum.

Mitchell, S. A., \& Blacková, M. J. (1999). Freud a po Freudovi. Praha: Triton 
Rabušic, L. (2002). Pronatalitní politika. In J. Kocourková, M. Kučera, M. Loužek, \& L. Rabušic. Populační politika - ano či ne (s. 47-64). Praha: CEP.

Shaver, P. R., Schwartz, J. C., Kirson, D., \& O'Conor, C. (1987). Emotion knowledge: Further explorations of a prototype approach. Journal of Personality and Social Psychology, 52(6), 1061-1086.

Shneidman, E. S. (1998). The suicidal mind. Oxford: Oxford University Press.

Slaměník, I. (2011). Emoce a interpersonální vztahy. Praha: Grada.

Spitz, R. A. (1965). The first year of life. New York: International Universities Press.

Sroufe, L. A. \& Fleeson, J. (1986). Attachment and the construction of relationships. In W. W. Hartup \& Z. Rubin (Eds.), Relationships and development (s. 51-71). Hillsdale: Lawrence Erlbaum Associates.

Vágnerová, M. (2012). Vývojová psychologie / Dětství a dospívání. Praha: Karolinum

\section{Autor}

prof. PhDr. Zdeněk Helus, DrSc., Univerzita Karlova, Pedagogická fakulta, Katedra primární pedagogiky, M. Rettigové 4, 11639 Praha, e-mail: zdenek.helus@pedf.cuni.cz

\section{On the psychology of an affectionate relationship: theoretical inspirations for pre-school education}

Abstract: The paper focusses on the personal approach to a child in the pre-school phase of their life, which constitutes a complex of interconnected developmental influences and culminates when the child enters kindergarten. The personal approach includes (a) regard to important characteristics of pre-school children (to its dependence, openness to experience, potential and developmental prognosis) and (b) regard to critical incidents in its previous development (primary relationships and attachment, separation-individuation tendency, the onset of assertive self, integration into kindergarten). An affectionate relationship is a precondition for child's development to progress naturally, in an uninhibited or deformed manner. An affectionate relationship of a kindergarten teacher has specific characteristics and finds realisation in her creative reflection on the child as a personality in forming.

Keywords: personal development, significant characteristics of childhood, affectionate relationship, situativness of love, critical developmental incidents, preschool education, empathically creative reflection 